日本一中国 国際共同研究「環境・エネルギー分野」

2020 年度 年次報告書

\begin{tabular}{|c|l|}
\hline 研究課題名 (和文) & 未来環境工ネルギー研究開発イノベーション拠点 \\
\hline 研究課題名 (英文) & $\begin{array}{l}\text { Japan-China Energy-Environmental CORE } \\
\text { (Japan-China E2C) }\end{array}$ \\
\hline 日本側研究代表者氏名 & 佐宗 章弘 \\
\hline 所属・役職 & 国立大学法人名古屋大学 副総長 \\
\hline 研究期間 & 2019 年 4月 1日〜 2024 年 3月 31 日 \\
\hline
\end{tabular}

1. 日本側の研究実施体制

\begin{tabular}{|c|c|c|}
\hline $\begin{array}{l}\text { ワークパッケージ } \\
\text { No. } 1\end{array}$ & \multicolumn{2}{|c|}{ C1 反応のためのへテログラフェン光触媒の合成と評価 } \\
\hline 氏名 & 所属機関・部局・役職 & 役割 \\
\hline 齋藤 永宏 & $\begin{array}{l}\text { 名古屋大学・未来社会創造機構· } \\
\text { 教授 }\end{array}$ & 研究リーダー \\
\hline 松尾 豊 & $\begin{array}{l}\text { 名古屋大学 未来社会創造機構 } \\
\text { 教授 }\end{array}$ & 実験・解析 \\
\hline 川角 昌弥 & $\begin{array}{l}\text { 名古屋大学 未来社会創造機構 } \\
\text { 特任教授 }\end{array}$ & 実験・解析 \\
\hline $\begin{array}{l}\text { ワン シャオヤ } \\
\text { ン }\end{array}$ & $\begin{array}{l}\text { 名古屋大学·未来社会創造機構· } \\
\text { 特任助教 }\end{array}$ & 実験・解析 \\
\hline
\end{tabular}

\begin{tabular}{|l|l|l|}
\hline \multicolumn{2}{|l|}{$\begin{array}{l}\text { ワークパッケージ } \\
\text { No. } 2\end{array}$} & \multicolumn{2}{l|}{ 熱マネジメント部材開発とエクセルギーに基づく LCA 評価 } \\
\hline \multicolumn{1}{|c|}{ 氏名 } & 所属機関・部局・役職 & \\
\hline 北 英紀 & 名古屋大学・工学研究科・教授 & 研究リーダー \\
\hline 山下 誠司 & 名古屋大学・工学研究科・助教 & 実験・解析 \\
\hline 窪田 光宏 & 名古屋大学・工学研究科・助教 & 実験・解析 \\
\hline
\end{tabular}




\begin{tabular}{|l|l|l|}
\hline $\begin{array}{l}\text { ワークパッケージ } \\
\text { No. } 3\end{array}$ & $\begin{array}{l}\text { 水素化と急速熱分解から成るシーケンシャル転換法によるバイオマ } \\
\text { スからオレフィの高選択製造 }\end{array}$ \\
\hline \multicolumn{1}{|c|}{ 氏名 } & 所属機関・部局・役職 & \\
\hline 則永 行庸 & 名古屋大学・工学研究科・教授 & 研究リーダー \\
\hline 町田 洋 & 名古屋大学・工学研究科・助教 & 水素化実験 \\
\hline 安田 啓二 & 名古屋大学・工学研究科・准教授 & 熱分析実験 \\
\hline
\end{tabular}

\begin{tabular}{|c|l|l|}
\hline \multicolumn{2}{|l|}{$\begin{array}{l}\text { ワークパッケージ } \\
\text { No. } 4\end{array}$} & \multicolumn{1}{|l|}{ チタン酸ナトリウムの高い吸着性能を用いた分離・浄化技術 } \\
\hline \multicolumn{1}{|c|}{ 氏名 } & \multicolumn{1}{|l|}{ 関・部局・役職 } & \multicolumn{1}{|c|}{ 役割 } \\
\hline 市野 良一 & $\begin{array}{l}\text { 名古屋大学・未来社会創造機構・ } \\
\text { 教授 }\end{array}$ & 研究リーダー \\
\hline 神本 祐樹 & $\begin{array}{l}\text { 名古屋大学・未来社会創造機構・ } \\
\text { 准教授 }\end{array}$ & 実験・解析 \\
\hline
\end{tabular}

\begin{tabular}{|l|l|l|}
\hline $\begin{array}{l}\text { ワークパッケージ } \\
\text { No. } 5\end{array}$ & \multicolumn{1}{|l|}{$\begin{array}{l}\text { 超臨界流体によるバイオ燃料の生産と、超臨界流体とプラズマによる } \\
\text { ナノコンポジット材料の創製 }\end{array}$} \\
\hline \multicolumn{1}{|c|}{ 氏名 } & \multicolumn{1}{|c|}{ 所属機関・部局・役職 } & \multicolumn{1}{|c|}{ 役割 } \\
\hline 後藤 元信 & 名古屋大学・工学研究科・教授 & 研究リーダー \\
\hline 高見 誠一 & 名古屋大学・工学研究科・教授 & 材料調整統括 \\
\hline 林 瑠美子 & $\begin{array}{l}\text { 名古屋大学・環境安全衛生管理 } \\
\text { 室・准教授 }\end{array}$ & 反実験統括 \\
\hline 神田 英輝 & 名古屋大学・工学研究科・助教 & バイオ燃料統括 \\
\hline 本田 真己 & 名城大学・理工学部・助教 & 分析統括 \\
\hline
\end{tabular}

\begin{tabular}{|c|l|l|}
\hline $\begin{array}{l}\text { ワークパッケージ } \\
\text { No.6 }\end{array}$ & ナノ複合材料の合成と表面機能化 \\
\hline \multicolumn{1}{|c|}{ 氏名 } & \multicolumn{1}{|l|}{ 所属機関・部局・役職 } & \\
\hline 近藤 博基 & $\begin{array}{l}\text { 名古屋大学・低温プラズマ科学 } \\
\text { 研究センター・研究リーダー }\end{array}$ \\
\hline 堤 隆嘉 & $\begin{array}{l}\text { 名古屋大学・低温プラズマ科学 } \\
\text { 研究センター・助教 }\end{array}$ & 解析統括 \\
\hline
\end{tabular}




\begin{tabular}{|c|l|l|}
\hline $\begin{array}{l}\text { ワークパッケージ } \\
\text { No. } 7\end{array}$ & \multicolumn{2}{|l|}{ ガス浄化用ミクロポーラス分離膜と吸着材の開発 } \\
\hline 氏名 & \multicolumn{1}{|l|}{ 所属機関・部局・役職 } & 役割 \\
\hline 萩尾 健史 & $\begin{array}{l}\text { 名古屋大学・未来社会創造機構・ } \\
\text { 助教 }\end{array}$ & 研究リーダー \\
\hline
\end{tabular}

\begin{tabular}{|c|c|c|}
\hline $\begin{array}{l}\text { ワークパッケージ } \\
\text { No. } 8\end{array}$ & \multicolumn{2}{|c|}{$\begin{array}{l}\text { 新規へテロカーボン•セラミックス電池ナノ材料の開発と電池高性能 } \\
\text { 化 }\end{array}$} \\
\hline 氏名 & 所属機関・部局・役職 & 役割 \\
\hline 齋藤 永宏 & $\begin{array}{l}\text { 名古屋大学・未来社会創造機構・ } \\
\text { 教授 }\end{array}$ & 研究リーダー \\
\hline 関 隆広 & 名古屋大学・工学研究科・教授 & 研究リーダー \\
\hline $\begin{array}{l}\text { ナラプラワッポ } \\
\text { ン リンヤラッ } \\
\text { ト }\end{array}$ & $\begin{array}{l}\text { 名古屋大学・未来社会創造機構· } \\
\text { 特任助教 }\end{array}$ & 実験・解析 \\
\hline
\end{tabular}

\begin{tabular}{|c|l|l|}
\hline $\begin{array}{l}\text { ワークパッケージ } \\
\text { No.9 }\end{array}$ & $\begin{array}{l}\text { 種元素ドープカーボンと機能性遷移金属酸化物からなる酸素発生·還 } \\
\text { 元用複合触媒材料の開発 }\end{array}$ \\
\hline \multicolumn{1}{|c|}{ 氏名 } & \multicolumn{1}{|c|}{ 所属機関・部局・役職 } & \multicolumn{1}{|c|}{ 役割 } \\
\hline 石崎 貴裕 & 芝浦工業大学・工学部・教授 & 研究リーダー \\
\hline 苗 蕾 & 芝浦工業大学・工学部・教授 & $\begin{array}{l}\text { 異種元素ドープカーボンと酸化物ナノ } \\
\text { 粒子からなる複合触媒材料の合成と評 } \\
\text { 価 }\end{array}$ \\
\hline
\end{tabular}

\begin{tabular}{|c|c|c|}
\hline $\begin{array}{l}\text { ワークパッケージ } \\
\text { No. } 10\end{array}$ & \multicolumn{2}{|c|}{ 光-電気-微生物処理の融合による高度污染水処理システムの創製 } \\
\hline 氏名 & 所属機関・部局・役職 & 役割 \\
\hline 寺島 千晶 & $\begin{array}{l}\text { 東京理科大学 総合研究院 教 } \\
\text { 授 }\end{array}$ & 研究リーダー \\
\hline 鈴木 孝宗 & $\begin{array}{l}\text { 東京理科大学 総合研究院 講 } \\
\text { 師 }\end{array}$ & 光触媒・水中プラズマを用いた浄水 \\
\hline 近藤 剛史 & $\begin{array}{l}\text { 東京理科大学 理工学部 准教 } \\
\text { 授 }\end{array}$ & BD D電極を用いた浄水 \\
\hline 手嶋 勝弥 & 信州大学 学術研究院 教授 & イオン交換結晶を用いた浄水 \\
\hline
\end{tabular}


2. 日本側研究チームの研究目標及び計画概要

エネルギ一有効利用技術（電池、触媒）、環境中の粒子等を除去する技術（浄化）、地球温 暖化の原因となる二酸化炭素の回収・固定化技術等 (地球温暖化対策技術) の開発を進める。 個々の技術シーズを深化させるとともに、産業界の二ーズに基づき、各技術の融合を行う。 中国サイトとなる上海連携拠点にテク二カルプロデューサーを配置し、両国の産業界との共 同研究を推進する。

\section{3. 日本側研究チームの実施概要}

2020 年度はコ口ナ禍での共同研究・連携活動となり、目的達成するために当初予定して いた方法を変更し、随時、オンライン、ライブ、配送などの手法の検討を進めた。この結 果、当初予定とした目標を概ね達成することができた。これは、Zoom の有償契約が大学 として支援があったこと、中国サイドが当初より Zoom を使用していたことから、年度当 初より、円滑なオンラインによる共同研究の遂行スキームを構築できたためである。ま た、上海交通大学から派遣され、本プロジェクトの研究に従事している若手研究者も共同 研究活動の円滑な推進に大きく貢献している。

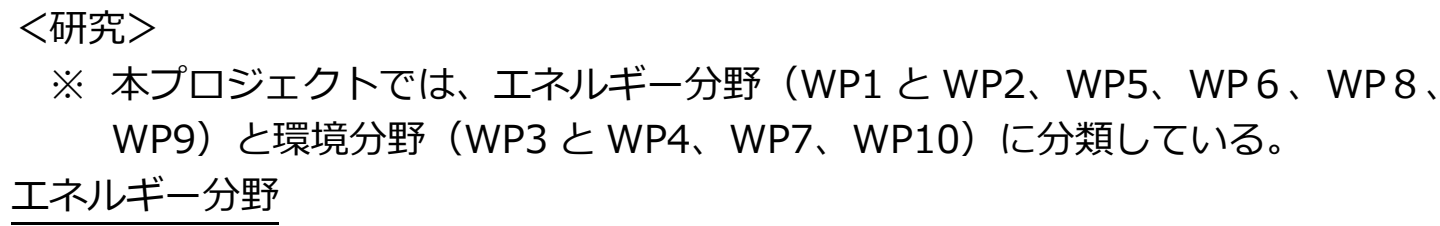

WP1： メタンを改質しメタノールに変換する新たな光触媒用へテログラフェン開発を進 めており、合成した触媒の光触媒二酸化炭素還元性能の試験では、欠陥と窒素含有グラフ エンの導入により、光触媒性能の向上が示唆された。

WP2：熱マネジメント用部材として、溶融状態でも形状を維持できる「自立型溶融塩 PCM (phase change material)) を開発し、これまでの成果である廃ケイ素由来の $\mathrm{Si}_{3} \mathrm{~N} 4$ で作成したシェルに内包し、新奇なマルチマテリアルー高温蓄熱用コアシェル複合体の可 能性を示した。また、LCA 評価として、独自に開発したソフトにより、複数の窒化ケイ素 製造のプロセスシステムのエクセルギー解析を実施し、事前検討段階における省エクセル ギー化の指針を得た。

WP 5： 超臨界流体とプラズマによるナノコンポジット材料開発では高圧力下ほど均一な ナノ粒子が合成された。色素の分解に対する触媒効果を調べたところ、カーボン被覆 $\mathrm{TiO} 2$ 粒子では良好な触媒効果が確認された。また、流通式気液界面プラズマキャピラリー反応 器を作成し、Ce 酸化物ナノ粒子を調製した。また、超臨界アルコール中でのバイオ燃料の 合成における固体触媒の効果について検討をし、触媒が効率的に働き反応温度を低下でき ることが分かった。

WP 6： ナノ複合材料合成において、超高速合成技術の確立を目的とし、ナノグラフェン 合成機構の解明を進めている。ナノグラフェンの結晶性を向上させる OH ラジカルの数、 十分に解離されず反応場に残つた CxHy の存在の 2 点が、アルコール種の変化による結晶 性の違いに寄与していることが示唆された。またナノグラフェンの結晶成長には、副生成 物および反応活性種 CxHy は寄与しておらず、C2 ラジカルがメインであることが示唆され た。 
WP 8： 液中プラズマ法を用いて、カチオン窒素ドープカーボンで単層カーボンナノチュ ーブをラッピングしたカチオン窒素ドープカーボンラッピング単層カーボンナノチューブ を合成し、電池材料に用いるために導電率の改善を進めた。CN-C@SWCNT の導電率は 330 S.cm-1 であつた。このように、 $180 \mathrm{~S} \cdot \mathrm{cm}-1$ （前年度達成値）以上の導電率を持つ CN-C@SWCNT が作製できた。

WP 9： 液中プラズマ法や水熱合成等の液相法を利用して 5at.\%以上の窒素含有率の力一 ボンを合成する技術を確立した。これらのカーボン材料は ORR に対する触媒性を示した。 ピリジン型窒素は 4 電子反応を促進させ、熱処理でアミノ基が表面から脱離し，ピリジン 型窒素及びグラファイト型窒素の結合種の割合が増加したためと考えられる。また、酸化 マンガンナノ粒子の合成技術を開発した。合成した酸化マンガンナノ粒子は ORR と OER に対する触媒性を示した。

環境分野

WP 3： プラスチック素材等の原料となる基幹化学品であるオレフィン（エチレンやプロ ピレン）を、再生可能資源であるバイオマスから、石油化学の生産速度に匹敵するスルー プットで製造するための新規転換反応スキームを開発中。中国側 Huo 教授のグループとの 触媒技術亡名大のプロセス技術を組み合わせ、・バイオマス水素化とそれに続く急速熱分 解によるオレフィン製造、・非貴金属触媒によるバイオマス誘導体の化成品中間原料への 完全転換、等の成果を得た。

WP 4 ：工業排水に含まれる亜鉛等の重金属の分離・回収能に優れた高機能な吸着材創製 を目指している。Zn-Ni 合金めつきの処理排水に含まれると想定される亜鉛以外の金属イ オン種の調査とチタン酸ナトリウム構造の亜鉛吸着性能に対する影響を調査し、目標の $2 \mathrm{mg} / \mathrm{L}$ 以下まで亜鉛が除去できるか検討した。 $\mathrm{Na}_{2} \mathrm{Ti}_{3} \mathrm{O}_{7}$ 相で亜鉛とニッケルが共存する溶 液にて吸着試験を行ったところ、高い亜鉛選択性を示し、亜鉛を目標の $2 \mathrm{mg} / \mathrm{L}$ 以下まで除 去できることが確認できた。

WP7： 自動車や工場・発電所等の排気ガスに含まれる大気污染物質である微小粒状粒子 (PM2.5)や酸性ガス $\left(\mathrm{CO}_{2} 、 \mathrm{SO}_{\mathrm{x}} 、 \mathrm{NO}_{\mathrm{x}}\right)$ の分離・浄化能に優れた高機能な吸着材およびフィ ルターの創製を目指している。昨年度開発した $\mathrm{CO}_{2}$ 分離に適すると思われる 3 種のミクロ ポーラス材料を緻密な膜状に形成する方法の確立に取り組んだ。その結果、3 種中 2 種の ゼオライト構造に関して触媒や種結晶として使用できる結晶形態・結晶粒子径の制御がで きるようになった。また、同 2 種については目標であつた膜の緻密化にも成功した。

WP10：光-電気-微生物処理から成る浄水システムの開発を目指している。光触媒とボ ンドープダイヤモンド(BDD)電極を組み合わせた複合電極を作製し、光電気触媒反応に基 づく浄水を実施した。併用した浄水では、各々単独で浄水し分解した場合より活性酸素種 （オゾンガス・過酸化水素）が多くなり、相乗効果が見られ、促進酸化による水処理が起 きていることが実証できた。実環境水中で検出される残留医薬品（スルファメトキサゾー ル $(S M X))$ で試験を行ったところ同様であったことから、本浄水システムの有効性が示唆 された。 
<拠点形成>

拠点活動では、共同研究拠点を設置するための契約を締結し、上海交通大学内に本プロ ジェクトの拠点を設置した。拠点の設置についてもコロナ禍の影響を受けた。渡航・往来 に代わり、リモート会議を駆使し、コミュニケーションを確保することで計画通り進め た。

本研究期間終了後の拠点の持続的発展については、上海連携拠点が日中民間企業の積極 的な研究開発投資を誘導するようにする。本学の次期中期計画では、本学が有する中国交 流センターの機能（教育、交流）と本プロジェクトで設置する拠点機能（研究開発・産学 連携）を統合し、上海交通大学内の全中国向けの常設機関として発展させることを掲げ る。 